\title{
Recovering Reformed catholicity
}

\author{
Stafford Carson
}

The themes of this symposium are reminiscent of papers prepared for the Church of Scotland Panel on Doctrine set up in 1978. In his introduction to those published papers on the Westminster Confession of Faith, Professor Heron said this:

Some feel that continued adherence to the Confession is a vital bulwark of the Church's faith, and indeed of its identity. Others are convinced that the qualifications with which the Confession is hedged about make the adherence required of ministers and elders a mere formality, largely meaningless and in practice ineffectual, and the Church must express its doctrinal basis with greater definiteness than the Confession can enable. Others again recognize the ambiguity of the status quo, but see advantages in leaving matters as they are. ${ }^{1}$

He noted some of the main questions that were being asked at that time:

How sound is the general teaching and tone of the Confession? How far is it time-conditioned, and how far might it still be seen as a Confession for today?

Does the Confession function effectively as the principal subordinate standard of the Church? [...] Could it function more effectively - or alternatively, is a principal subordinate standard necessary at all?

How far is the church at liberty to modify the standing of the Confession? What consequences for the Church's own identity might follow?

What practical alternatives might there be to the present position? What grounds might be advanced for preferring them? Or is the present position essentially satisfactory? ${ }^{2}$

\footnotetext{
${ }^{1}$ Alasdair I. C. Heron, ed., The Westminster Confession in the Church Today: Papers Prepared for the Church of Scotland Panel on Doctrine (Edinburgh: Saint Andrew Press, 1982), 2.

${ }^{2}$ Ibid, $3 f$.
} 


\section{Recovering Reformed catholicity}

In the intervening years there has been considerable discussion, but the fact that we are here discussing these issues once more indicates that the questions posed in 1982 remain as pressing questions for many people today.

There are a number of additional questions we might ask as we come to consider the theology of the Westminster Confession of Faith and Catechisms. What has changed in the past forty years? Are we in a better position to address these issues than we were almost half a century ago? What has happened in terms of both the condition and state of the church, as well as the thinking of ordinary people, that would make the theology and content of a seventeenth-century confession of faith in any way relevant or meaningful today? Why would a consideration of the theology of the Westminster Standards be a pressing issue for us as Reformed Christians or as Reformed churches?

I believe that we can address these issues with renewed confidence and with greater resources at hand to help us than was the case in the early 1980s. In the past forty years there has been a renewed interest in the work of the Westminster Assembly and in the nature of seventeenth-century Reformed Orthodoxy more generally, and which sees the Confession as a statement of British Reformed Orthodoxy at the beginning of the period which Richard Muller has called 'High Orthodoxy'. There has been a more detailed exploration of the discussions and debates of the Assembly through an examination of its minutes.

In 2012 the Assembly's minutes and papers edited by Chad Van Dixhoorn, were published by Oxford University Press in five volumes - some one million words - the fruit of eleven years of full-time work. ${ }^{3}$ For more than 350 years the original minutes of the debates taken by the scribe Adoniram Byfield had lain unpublished. It was a manuscript 550,000 words long and penned in some of the most undecipherable handwriting imaginable, but containing many of the speeches and arguments made on the floor of the Assembly. Furthermore, this publication contains the documents and letters written by the Assembly itself, some of which have only recently been discovered. It is a veritable treasure trove for understanding the context and the purpose of the Westminster Confession.

Initially the Confession might appear to be uncompromising, rigid and overly precise. However, the minutes show it to be a highly nuanced document. There are some doctrines it explicitly rejects and other areas in which it is silent or deliberately ambiguous in order to secure consensus.

I want to propose that the content and teaching of that Confession continue to be relevant for the Reformed churches today, and that if we are, with any credibility, going to claim to be a Reformed church that stands in the mainstream of Reformed catholicity we cannot simply relegate the Westminster Confession

${ }^{3}$ Chad Van Dixhoorn, ed., The Minutes and Papers of the Westminster Assembly 1643-1652, 5 volumes (Oxford University Press, 2012). 


\section{Recovering Reformed catholicity}

to the status of an honoured historical document. In adopting that position I am aware of the challenges that we face, especially when we remember that there are powerful forces at work within our modern world that militate against adherence to historic statements of the Christian faith.

Alister McGrath describes one view where the Reformed faith is engaged in an endless cycle of birth, maturing, aging and death which leads to renewal and re-formulation. The relentless energy and creativity of one generation gives rise to new thoughts, new expressions and new understandings of the faith. But a later generation becomes anxious because the original energy and enthusiasm of the movement appears to be evaporating and leaking. It therefore tries to preserve it by petrification. They hope that by freezing the original vision they will be able to preserve its energy and vitality. But all that happens is that a structure becomes petrified, and the life-giving vision is lost. 'However perfectly preserved in the entomologist's specimen room, the butterfly is still dead."

So it is claimed that the use of 'confessions of faith' as a means of preserving the insights of the Reformation led to a very conformist attitude towards religion rather than a living and active faith in God. It was a matter of outward conformity and observance without any inward spiritual reality.

In commending the theology of the Westminster Standards, I am not wishing to 'freeze' one moment in the past and claim that strict subscription or adherence to these documents will guarantee the health and vitality of the church. Yet I am convinced that the Westminster Standards contain the essential DNA of Reformed catholicity, and that, even though the church will express herself differently in all the various contexts of our contemporary world, there is an undisputed theological continuity that runs from the teaching of the Bible, through the apostles, the church fathers and through the Reformation of the sixteenth century to today. If that continuity is recognized and studied, it will serve to strengthen, enrich and invigorate the church as she seeks to respond to the current issues.

I come to this issue, not as an academic theologian, but as a minister, a pastor and a preacher who has been involved in ministry training and who is concerned to prepare students for effective and fruitful ministry. If our students are to be given the tools for ministry in an increasingly challenging context, and against the background of a quickly-changing ecclesiastical landscape, then a key part of their training must be a clear understanding both of what the Bible teaches and an appreciation for the history of thought and reflection on central concepts of catholic and Reformed Christianity. In discharging that task, the study of the Westminster Standards is critical.

\footnotetext{
${ }^{4}$ Alister E. McGrath, Christianity's Dangerous Idea: The Protestant Revolution: A History from the Sixteenth Century to the Twenty-First (New York: Harper Collins, 2007), 463.
} 


\section{Recovering Reformed catholicity}

We should also understand that congregational ministry is the location for the re-discovery of Reformed catholicity. This is not simply a scholarly task. As Todd Billings has pointed out, underpinning this desire for a recovery of Reformed catholicity is a theological conviction, that the ministry of the Word and sacrament is a central site for God's activity in, through and to the world. Word and sacrament are 'the central means by which God carries forward his 'mission' to the world. Today's church needs pastor-theologians who are willing to dig deep into the biblical insights of the catholic and Reformed treasury of teaching and practices, rather than being guided by the latest whims and trends. ${ }^{5}$

This quotation from John Webster summarizes the issues very clearly:

We should be under no illusion that renewed emphasis upon the creed will in and of itself renew the life of the church: it will not. The church is created and renewed through Word and Spirit. Everything else - love of the brethren, holiness, proclamation, confession - is dependent upon them. Yet it is scarcely possible to envisage substantial renewal of the life of the church without renewal of its confessional life. There are many conditions for such renewal. One is real governance of the church's practice and decision-making not by ill-digested cultural analysis but by reference to the credal rendering of the biblical gospel. Another is recovery of the kind of theology which sees itself as an apostolic task, and does not believe itself entitled or competent to reinvent or subvert the Christian tradition. A third, rarely noticed, condition is the need for a recovery of symbolics (the study of creeds and confessions) as part of the theological curriculum - so much more edifying than most of what fills the seminary day. But alongside these are required habits of mind and heart: love of the gospel, docility in face of our forebears, readiness for responsibility and venture, a freedom from concern for reputation, a proper self-distrust. None of these things can be cultivated; they are the Spirit's gifts, and the Spirit alone must do his work. What we may do - and must do - is cry to God, who alone works great marvels. $^{6}$

My experience in teaching and preparing students for ministry is that this emphasis is one which they find energizing and stimulating. Among students who come from our two main traditions in Ireland, there has been an overwhelmingly

${ }^{5}$ J. Todd Billings, "Afterword: Rediscovering the Catholic-Reformed Tradition for Today: A Biblical, Christ-centered Vision for Church Renewal", in Michael Allen and Scott R. Swain, Reformed Catholicity: The Promise of Retrieval for Theology and Biblical Interpretation (Grand Rapids, Mich.: Baker, 2015), 157.

6 John Webster, "Confession and Confessions", in Confessing God: Essays in Christian Dogmatics II (London: T\&T Clark, 2005), 83. 


\section{Recovering Reformed catholicity}

positive response to courses where Christian belief and practice are located within this mainstream of Reformed catholicity.

In a similar vein, Michael Allen sets the context for the consideration of confessional issues:

The nature of confessions has been located by Reformed theology in the economy of the Gospel. They serve as auxiliaries - spiritual, yet subordinate - to point the congregation to the Word of God. They function ministerially, then, on behalf of that magisterial Messiah who is alone Lord of the church. In so doing, they are called to an expository task: to show that their judgments derive from the testimony of the prophets and apostles. They bind in as much as they echo and extend those scriptural words of life. Yet these qualifications characterize and in no way nullify the vital place of confessions within the life of the Christian community. By the Word of Christ and the illumination of the Spirit, they do serve as authorized witnesses to guide the church's own witness and worship. ${ }^{7}$

So what are we to make of the actual teaching and theology of the Westminster Confession of Faith? The view of the Confession that developed through much of the twentieth century often pitted Calvin against the Calvinists. According to this argument, Calvin's dynamic Biblicism was lost by his successors. In particular, Theodore Beza, who was Calvin's successor at Geneva, introduced Aristotelian philosophical methodology into Reformed theology. The result was a thoroughgoing rational theology in which logic and reason were paramount. Doctrines were deduced from masterful premises. Reason was given a priority and the biblical text was squeezed into a rigidly imposed grid. The tensions that were evident in Calvin, based on his determination to follow the Bible, were ironed out by logic and reason in the statements of the Westminster Confession and catechisms.

So the Westminster Assembly fits into the Calvinist camp with its doctrine logically deduced from the premise of the eternal decree of God, and the history of salvation demarcated into two distinct covenants, the covenant of works before the fall and the covenant of grace after it. The Westminster Confession of Faith is therefore said to be an example of Reformed scholasticism. This critique has been part of an attempt to detach the theology of the immediate heirs of the Reformation from the theology of the Reformation itself, and then, once that rift is assumed and accepted, to claim the Reformers as the forerunners of modernity.

${ }^{7}$ Michael Allen, "Confessions", in The Cambridge Companion to Reformed Theology, ed. Paul T. Nimmo and David A. S. Fergusson (Cambridge University Press, 2016), 28-43, at p. 32. 
The criticism offered is that Protestant orthodoxy in general has been declared to be 'dry', 'rigid' and 'dead'. It has been accused of being 'speculative', 'metaphysical', 'predestinarian' and 'legalistic'. It is guilty of proof-texting and of being rationalistic and philosophical. In response to that, Richard Muller comments that 'no theology can be all of those things at the same time, in the same place, and in the same way'. ${ }^{8}$ Muller points out that the development and institutionalization of the Reformed tradition can best be defined and the nature of its continuity with the Reformation understood when the two terms typically used to characterize it are properly understood: orthodoxy and scholasticism. ${ }^{9}$

Muller claims that an examination of the sources of Reformed orthodoxy clearly sets aside the stereotypes of this theology. He says that the standard claims about central dogmas, legalism, rationalism and proof-texting Biblicism fail because they are too simplistic. It is too simple to deduce a theology from one principle, and by contrast, it is exceedingly complex to construct that theology out of exegetical arguments nuanced by extensive knowledge of the biblical and cognate languages, attention to the exegetical tradition, and acknowledgement of the significance of creeds, confessions and the wealth of the tradition.

The argument Muller makes is that few, if any, modern theologians who criticize the older orthodoxy can claim a comparable grasp of Scripture, biblical languages, confessional norms, the great tradition of Christian meditation, and a coherent method and use of philosophical categories. The key question, he says, might be posed in these terms: understanding that all theology requires study, reflection and some degree of translation into the living vernacular, which theology, that of the seventeenth or twentieth centuries, provides the better basis for interpreting the sense of Scripture, for constructing a functional language about God, for thinking and teaching within a confessional church, for addressing the great issues of the identity and work of Jesus Christ, the problem of sin and the gift of salvation? Muller says that the answer is quite simple, "if only because of the diversity of modern theology in its desire for newness of expression and its frequent refusal to speak the language either of Scripture or the church'. ${ }^{10}$

So in recent decades a growing movement has challenged the twentiethcentury analysis. Historians have re-examined the Reformed orthodox materials, including the Westminster Standards, from several perspectives. One key revisionist insight is methodological, positing that theological writing must be

\footnotetext{
${ }^{8}$ Richard A. Muller, "Sources of Reformed Orthodoxy: The Symmetrical Unity of Exegesis and Synthesis", in A Confessing Theology for Postmodern Times, ed. Michael S. Horton (Wheaton, Ill.: Crossway, 2000), 44.

9 Richard A. Muller, "John Calvin and Later Calvinism: The Identity of the Reformed Tradition", in The Cambridge Companion to Reformation Theology, ed. David Bagchi and David C. Steinmetz (Cambridge University Press, 2004), 130-49.

${ }^{10}$ Muller, "Sources of Reformed Orthodoxy", 59.
} 
understood in its context and according to its purpose - it is not enough simply to ask what the sources say but rather the historian must consider what they were designed to $d o$. This is one of the reasons why the more recent studies of the Assembly and its work and the background and perspective of its formulators provide us with such helpful resources in assessing the nature of the Westminster Standards.

The Confession is as concerned with Socianianism and Antinomianism as it is with the errors of the Church of Rome. This is one of the reasons why it is so relevant for us today. By 1642, the major enemy was not found in Madrid [with the Spanish Jesuits] but in London [with the antinomian underground]. The antinomians like John Saltmarsh, Tobias Crisp and John Eaton viewed themselves as the true defenders of the free grace of the gospel, but to the divines they had departed from Reformed Orthodoxy on several key points of doctrine. ${ }^{11}$

A second key insight is that Reformed Orthodoxy stands in a critical, but largely positive, relation to late medieval theology.

During the era of orthodoxy - namely, the late sixteenth and seventeenth centuries - Protestant theology was framed both positively and negatively against the background of both distant and recent theological tradition. The Reformed orthodox theology is characterized by a conscious catholicity. ${ }^{12}$

The basic contention is that Reformed theology needs to be understood as part of the wider Western theological tradition stretching back into medieval Thomism, Augustinian anti-Pelagianism, and the Patristic period. So with regard to the Confession, we need to be aware that the Westminster divines were concerned to demonstrate their catholicity. The minutes reveal that they had an excellent grasp of the writings of the church fathers and the medieval theologians. For instance, in their debates we find that Augustine is cited as frequently as Calvin, and Cyprian the same number of times as Luther. There is also extensive correspondence between the Westminster divines and other Reformed churches.

The Westminster divines considered themselves to be Reformed Catholics and they therefore didn't want to isolate themselves from the rest of the church, but they saw their broader engagement with other periods of history and other theological traditions as evidence of their catholicity. This perspective is particularly relevant for the task of mission in Ireland where we seek engagement

${ }^{11}$ See Whitney G. Gamble, Christ and the Law: Antinomianism at the Westminster Assembly (Grand Rapids, Mich.: Reformation Heritage Books, 2018). Also her chapter on the Assembly in the forthcoming The History of Scottish Theology, Volume 1: Celtic Origins to Reformed Orthodoxy, ed. David A. S. Fergusson and Mark W. Elliott (Oxford University Press, 2019).

${ }^{12}$ Richard A. Muller, After Calvin: Studies in the Development of a Theological Tradition (Oxford University Press, 2003), 47. 


\section{Recovering Reformed catholicity}

with those from the Roman Catholic tradition and desire to see the advance of a non-sectarian Reformed church across the island.

A third revisionist insight is that Reformed Orthodoxy has a strong emphasis on exegesis. In the past, the old cliché was that post-Reformation theology was an era of dogma, not exegesis. The idea that the divines were only interested in systematic theology and proof-texting and did not engage carefully with the biblical text has been successfully challenged. Recent studies however have highlighted how many of the Reformed orthodox theologians at the Assembly were often sophisticated exegetes with superb linguistic skills and their doctrine was highly exegetical.

Biblical exegesis was the Assembly's primary source of theology. This is strikingly evident from the record of debates. The divines were constantly discussing the meaning of passages from the Old Testament and New Testament. Their theology was grounded, not on abstract logical speculation or a chain of casual deductivism, but on their grappling with the biblical text in its original languages, in interaction with the history of interpretation, not only in the Reformed churches, but also in the medieval and patristic periods.

A number of the Westminster divines participated in the compilation of an important publication of the seventeenth century. The actual title of the work in its first edition of 1645 was Annotations upon all the books of the Old and New Testament, wherein the text is explained, doubts resolved, Scriptures paralleled, and various readings observed by the joynt-labour of certain learned divines. There was a second edition in 1651, and a full third edition in 1657. The first edition exceeded 900 folio pages.

Muller maintains that the evidence is that there is a strong relationship between the exegetical tradition represented in part by the English Annotations and the citations of Scripture in the Westminster Confession of Faith. It is not a neat oneto-one correlation as if the Confession was written with consistent and precise references to the Annotations. The relationship is more subtle and variegated than that. Particularly it is important to note that the pattern of citing biblical proofs found in the confessional standards was not a form of rank proof-texting, as has sometimes been alleged of the Westminster Standards and the theological works of the seventeenth-century orthodox in general.

Rather, the confession and the catechisms cite texts by way of referencing an exegetical tradition reaching back, in many cases, to the fathers of the church in the first five centuries of Christianity and, quite consistently, reflecting the path of biblical interpretation belonging to the Reformed 


\section{Recovering Reformed catholicity}

tradition as it developed in the sixteenth century and in the beginning of the seventeenth. ${ }^{13}$

On the other hand, the Annotations stand in that tradition, in conscious reliance on the work of predecessors like Beza and other continental commentators, and provide an indication of the ways in which biblical texts were interpreted at the time of the Westminster Assembly. The correlation between the Confession and that exegetical tradition indicates that the authors of the Westminster Standards could be confident that their doctrinal statements did indeed reflect the teaching of Scripture. The added biblical proofs provided an avenue or a door into the teaching of Scripture for the readers of the confession and catechisms.

One example is the way in which the Westminster Confession addresses the difficult issue of the relationship between the Old Testament Mosaic law and the New Testament church. Chapter 19 of the Confession is a statement of the theology of the law of God that is representative of what we might generally call Protestant scholasticism. It is a statement that was forged in the fires of theological controversy, and was undoubtedly written with a view to the re-emergence of the antinomians on the one hand and in opposition to the legalism of the papacy on the other hand. It was a statement where every clause was carefully considered. A recent doctoral study by Stephen Casselli contends that the work of the Assembly on this chapter was heavily influenced by Anthony Burgess.

As Casselli demonstrates, 'the Reformed scholastics believed this to be a distinction found within the Scriptures themselves' and they sought 'to draw out what is inherent in the text when one gives attention to its linguistic phenomena'. ${ }^{14}$

Burgess's Vindiciae Legis, his lectures on the law of God, answering the 'antinomian errors of these times', shows that undergirding the Reformed view of the threefold character of the law there was a profound awareness of biblical exegesis and theology, redemptive history, and the christoscopic character of Scripture. ${ }^{15}$ While the categorisation language of moral, civil and ceremonial law, like the term Trinity, is theological rather than strictly biblical, this careful study

13 Richard A. Muller, "Either Expressly Set Down ... or by Good and Necessary Consequence': Exegesis and Formulation in the Annotations and the Confession", in Richard A. Muller and Rowland S. Ward, Scripture and Worship: Biblical Interpretation and the Directory for Public Worship (Phillipsburg, N.J.: P\&R Publishing, 2007), 81.

${ }^{14}$ Stephen J. Casselli, Divine Rule Maintained: Anthony Burgess, Covenant Theology, and the Place of the Law in Reformed Scholasticism (Grand Rapids, Mich.: Reformation Heritage Books, 2016), 85.

${ }^{15}$ Anthony Burgess, Vindicia legis or, A vindication of the morall law and the covenants, from the errours of papists, Arminians, Socinians, and more especially, Antinomians. In XXIX. lectures, preached at Laurence-Jury, London (London, 1646), "License". Available at: https://www.westminsterassembly.org/wp-content/uploads/2018/03/Burgess-Vindiceae-textcomplete.pdf 
of Burgess demonstrates that the concepts themselves were rooted in differentiations made in the text of the Old Testament itself.

One of the misunderstandings of the scholastic theologians of the later sixteenth and early seventeenth centuries in particular involves a narrow reading of their historical self-consciousness. Burgess and his contemporaries did not conceive of themselves first as Calvinists. They perceived themselves as Reformed and catholic in the broadest sense. That Burgess understood himself in this way is evident throughout his writings. He is found to be in constant dialogue with the entire tradition of Western theology, medieval and before. His theology cannot be understood apart from some appreciation of this catholic context.

What is striking is the number of times Burgess cited the church fathers, Augustine in particular. There are fifty-seven citations of Augustine, more than for any other writer: twenty-one of Chrysostom, and twelve of Tertullian. Other important early writers to which he made reference include Athanasius, Basil, Clement of Alexandria, Gregory Nazianzus and Irenaeus.

For Burgess and his contemporaries, authors of antiquity were viewed as more significant authorities than the relatively recent Reformed writers. [...] Adherence to the patristic tradition, mediated through Augustine, was the goal toward which Burgess and his orthodox contemporaries would strive. His theology $[\ldots]$ was constructed with self-conscious reference to the catholic patristic tradition. ${ }^{16}$

For many years little attention was given to the ways in which the Protestant theologians of the sixteenth and seventeenth centuries appropriated patristic writings as sources for their theology. But in recent years that area has been opened up and has shown that these sources were of profound importance to the Protestant orthodox.

Again, the Protestant orthodox use of the church fathers must be understood as the direct outgrowth of the great Reformers' assumption that the Reformation was reformation of the catholic church, that Rome had fallen away, and that the best of the tradition could not only be appropriated by, but belonged by right to, the Reformation and its descendants.

When we consider the material content of the Westminster Confession of Faith, it becomes clear that in key areas, the Westminster Confession of Faith maintained the catholic consensus and in specific areas doctrines were Reformed in accordance with the teaching of God's Word. The Westminster Confession gives attention to the practical application of dogmatic issues. Particularly, it is

${ }^{16}$ Casselli, Divine Rule Maintained, 137. 


\section{Recovering Reformed catholicity}

concerned with matters like the use of the Holy Scriptures, the Christian life, and the worship and sacraments of the church. It represents a largely cohesive picture of Reformed orthodoxy and catholicity, and has immense practical value for contemporary ministry.

The Confession's opening chapter reflects one of the chief tenets of the Reformation's principle of sola Scriptura. It describes key principles such as the analogy of Scripture, the limits of the canon of Scripture, the sufficiency of Scripture, and the vital importance of good and necessary consequences. ${ }^{17}$ But we need to appreciate that the Reformed churches of the sixteenth century lived out their commitment to sola Scriptura in a catholic context.

Principled commitment to biblical authority as the ultimate determining factor for all faith and practice did not lead to diminishing concern for ecclesial authority or waning reception of church traditions. Rather sola Scriptura aided the course of such reception: retrieving the fullness of the catholic past while cognizant of the ever-present need for ongoing reform. ${ }^{18}$

Critics have blamed the doctrine of the covenants for all that is wrong with the Confession. Particularly, that Calvin knew nothing of the dual covenant structure of works and grace and that 'these theological innovations' were the work of Calvin's successors. In the period of High Orthodoxy, covenant theology became a defining feature of Reformed theology.

Michael Allen says that it is worth noting that the covenant attained higher prestige in the Reformed tradition due to two major factors. First, the terminology of covenant was emphasized as a result of a return to primary sources inspired by the humanist movement, and by extension, as a result of the biblical frequency of discussing covenants throughout the course of the Scriptures. This careful study of the texts led to the conclusion that communion with God takes various forms dependent on historical location. Second, the covenant terminology was employed as a rubric under which the connections between Old Testament and New Testament might be explored. This was part of the debate with the Roman Catholic church on the one hand and the Anabaptists on the other. Rome failed to note the newness of our current covenantal reality whereas the Anabaptists threatened a complete separation of the New from the Old. Thus the bicovenantal structure of covenant of works and covenant of grace became a structuring

${ }^{17}$ J. V. Fesko, The Theology of the Westminster Standards: Historical Context and Theological Insights (Wheaton, Ill.: Crossway, 2014), 93.

${ }^{18}$ Allen and Swain, Reformed Catholicity, 70. 
principle in the Westminster Confession, although it had been developed by Caspar Olevian and others by the 1560 s.

The doctrine of Christ is described under the rubric of Christ as the federal head, the second Adam, the surety of the covenant of grace. Its doctrine of Christ rests squarely upon the Scriptures but also extends its hands across the centuries to express its agreement with the teaching of the ancient church in its ecumenical councils. Along with the Reformers, the Westminster divines affirmed their belief in the full deity and humanity of Christ. But in line with other Reformed confessions they developed that doctrine in line with the ways Christ fulfilled the Old Testament offices of prophet, priest and king. The source of this development is often attributed to Calvin, but the threefold office of Christ, which so clearly emphasizes the unity of his person and work, had been spoken of in the earliest days of the church and appears in patristic authors such as Eusebius of Caesarea (c. 263-339) and medieval authors like Thomas Aquinas (c. 1226-74) and was anticipated by Johannes à Lasco (1499-1560) before Calvin.

Part of our larger task, then, is to examine each chapter of the Westminster Confession and to locate its content within this wider and broader stream of Reformed catholicity. That would take much longer than the time that is available to us today.

A Reformed theology of retrieval must help us perceive the processes and products by which the church receives and transmits apostolic teaching not simply as human cultural activities and artifacts but also as fruits of the Spirit. ${ }^{19}$

Time does not permit us to reflect on the documents of the Westminster Assembly as compromise documents. In a group of 150 people, compromise is inevitable and essential. Robert Letham says that if we leave aside the Assembly's exclusion of what it considered false (namely the distinctive teachings of the antinomians, Arminians, Roman Catholics, Lutherans and high church Episcopalians) and the well-known differences over ecclesiology between the Presbyterians and the Independents, there were clear distinctions, nuances and contours within what was considered acceptable doctrine. ${ }^{20}$

One example of these nuances is the subtle but important distinction in the handling of the ordo salutis. The approach in the Larger Catechism is different from that in the Confession. Instead of a purely logical order, the Catechism places the whole process of salvation under the umbrella of union and communion with

\footnotetext{
${ }^{19}$ Ibid., 25.

${ }^{20}$ Robert Letham, The Westminster Assembly: Reading its Theology in Historical Context (Phillipsburg, N.J.: P\&R Publishing, 2009), 111.
} 


\section{Recovering Reformed catholicity}

Christ in grace and glory (LC 65-90) and reaches its climax in a thoroughly Trinitarian view of glorification. These two perspectives exist side by side and the Assembly did not view them as incompatible.

In short, the Assembly, within limits, sought to be inclusive rather than exclusive. It sought to achieve the widest measure of agreement possible within acceptable limits of doctrine and practice. At times, it would say less than what a majority of its members would otherwise affirm.

One final point: This retrieval of Reformed catholicity through confessions like the Westminster Confession of Faith is an important task for the church today. In the most comprehensive study ever conducted on the beliefs of American youth, Christian Smith and Melinda Lundquist Denton identified moralistic therapeutic deism (MTD) as the core beliefs of many Christian young people. ${ }^{21}$ MTD says that God wants people to be good, nice and fair to each other; that the central goal in life is to be happy and to feel good about oneself; and that God does not need to be particularly involved in one's life except when he is needed to resolve a problem. The adoption of MTD is widespread and reflects not only the views of young people but also their parents. It constitutes a serious crisis for the Western church since it is neither biblical nor God-centred. It is a thoroughly individualistic, me-centred religion which is at odds with historic Christianity.

It seems clear to many that the renewal of the church, and the antidote to MTD and other false understandings of Christianity, is through the retrieval of our catholic and Reformed heritage. Those who are preparing for ministry, and those who are in ministry, need to be able to address current deformities of the Christian religion by accentuating an approach that re-discovers a biblical, Christ-centred path towards church renewal and that offers real hope to those suffer.

In a very moving description of his struggle with cancer, Todd Billings describes how the doctrines of classical theism were invaluable for him in his own personal suffering. By reaching back into the Christian tradition, he was strengthened and comforted in the knowledge that 'God's covenant love is so steady and powerful that, in Christ, suffering and death lose their dominion' over our lives. 'It is the steadiness of God's love', he says, 'that allows us to approach him amid the unsteadiness of our anguish and frailty. ${ }^{22}$ And in preparing people for ministry we need to allow them to access these great doctrines of our faith expressed in our Confession so that they minister effectively to those who are in need.

As Todd Billings puts it:

\footnotetext{
${ }^{21}$ Christian Smith and Melinda Lundquist Denton, Soul Searching: The Religious and Spiritual Lives of American Teenagers (Oxford University Press, 2005).

22 J. Todd Billings, "Undying Love: In Our Suffering, We Find Comfort in God's Impassibility”, December 2014, http://www.firstthings.com/article/2014/12/undying-love
} 


\section{Recovering Reformed catholicity}

[...] an approach that is both catholic and Reformed challenges the deep and often hidden assumptions that place the religious consumer in the center, and the drama of the Triune God on the sidelines. It opens up a place for ecclesial life and theological reflection that is wide and spacious, yet specified in its worship of the Triune God and rooted in theological conviction. It gives a path towards church renewal in which our consumer priorities are gradually displaced by the Spirit as we are incorporated into Christ and his corporate body, fed at the Pulpit and the Table as adopted children of the Father. Our stories as religious consumers are incorporated into the dying and rising of Christ by the Spirit - for our life is found in Christ and union with him. ${ }^{23}$

The Westminster Confession of Faith is not perfect or flawless, but it is rich. It is a text that leads us back to Scripture, back to God himself, and it has a surprising vitality and relevance for our own ecclesiastical and cultural moment. It deals with communal concerns such as civil government, oaths and vows, and marriage. It offers discussions on Christian liberty and church-state relations. Supremely, it stirs up a hunger and an appetite for God himself.

After all, as the Apostle Paul once wrote to the Romans, we serve the One 'of whom, through whom, and to whom, are all things'. And the Westminster Confession of Faith reminds us that we celebrate the God in whose 'sight all things are open and manifest', whose 'knowledge is infinite, infallible, and independent' of anything in his creation. That description leaves us speechless before a majestic Triune God who is 'most holy in all His counsels, in all His works, and in all His commands' - the one to whom 'is due from angels and men, and every other creature, whatsoever worship, service, or obedience He is pleased to require of them. ${ }^{24}$ It is that kind of rich and full description of God that we need to energize and renew us today.

Stafford Carson is Principal and Professor of Ministry at Union Theological College, Belfast.

${ }^{23}$ Allen and Swain, Reformed Catholicity, 144f.

${ }^{24}$ Westminster Confession of Faith, Chapter 2. 